\title{
Jurisdiction Territory Code
}

National Cancer Institute

\section{Source}

National Cancer Institute. Jurisdiction Territory Code. NCI Thesaurus. Code C93584.

A coded value specifying the geographical area or limits an entity has to make laws and enforce them. 